\title{
Effects of 1-Aminocyclopropane-1-carboxylic Acid Production on the Changes in the Polyamine Levels in Hiproly Barley Callus after Auxin Withdrawal
}

\author{
Yoshinobu Katoh, Tadao Hasegawa, ${ }^{*}$ Takao Suzuki* \\ and Taro FuJII** \\ Life Science Division, Hokkaido Institute of Public Health, \\ Sapporo, Hokkaido 060, Japan \\ * Department of Agricultural Chemistry, Tokyo University of Agriculture, \\ Setagaya-ku, Tokyo 156, Japan \\ **National Institute of Genetics, Mishima, Shizuoka 411, Japan
}

Received March 30, 1987

\begin{abstract}
Contents of polyamines and 1-aminocyclopropane-1-carboxylic acid (ACC) in Hiproly barley callus were examined under different culture conditions. After auxin withdrawal, the contents of free polyamines changed conversely to the contents of ACC. In the absence of auxin, incorporation of $\mathrm{L}-\left[3,4-{ }^{14} \mathrm{C}\right]$ methionine into polyamines and the activity of $S$-adenosylmethionine decarboxylase (SAMDCase) in the callus increased, then remained stable, but incorporation of L-[3,4$\left.{ }^{14} \mathrm{C}\right]$ methionine into $\mathrm{ACC}$, precursor of ethylene and ACC synthase activity once declined and increased again.

Aminooxyacetic acid (AOA) affected the increase in the levels of polyamines in the callus. 1Aminoisobutyric acid (AIB) had a slight effect on the polyamine production. The incorporation of $\mathrm{L}-\left[3,4-{ }^{14} \mathrm{C}\right]$ methionine into ACC and ACC synthase activity were inhibited by AOA, but not by AIB. AOA stimulated the activity of SAMDCase, and also enhanced the incorporation of L-[3,4$\left.{ }^{14} \mathrm{C}\right]$ methionine into polyamines in the callus. Methylglyoxal-bis(guanylhydrazone) (MGBG) greatly enhanced the ACC production. The rate of incorporation of $\mathrm{L}-\left[3,4-{ }^{14} \mathrm{C}\right]$ methionine into ACC and ACC synthase activity in the callus were significantly enhanced by MGBG. MGBG strongly inhibited SAMDCase activity and the incorporation of $\mathrm{L}-\left[3,4-{ }^{14} \mathrm{C}\right]$ methionine into polyamines. Moreover, the synthesis of polyamines was inhibited by MGBG.

These results suggested that in Hiproly barley callus ACC production has an important effect on changes in the polyamine levels, and that polyamine and ethylene biosynthetic pathways are regulated by competition against each other.
\end{abstract}

Putrescine, spermidine, and spermine are synthesized from arginine, ornithine, and methionine. In plants, putrescine is first synthesized from both arginine and ornithine through their decarboxylation,,2) and spermidine and spermine are formed from putrescine by transfer of the aminopropyl moieties from methionine. ${ }^{3)}$

Spermidine and spermine biosynthesis is closely related to ethylene evolution. Apelbaum et al. $^{4)}$ and Suttle ${ }^{5)}$ reported that ethylene production was regulated by exogenously applied polyamines and that ethylene inhibited polyamine formation. Robert et al. ${ }^{6}$ ) also reported that the levels of spermidine and spermine in carnation flowers were elevated by inhibition of the ethylene biosynthetic pathway. Even-Chen et al. ${ }^{7)}$ noted an increase in incorporation of methionine into polyamines when ethylene production was inhibited by aminoethyoxyvinylglycine in aged orange peel.

Ethylene is synthesized through the conversion of methionine to $S$-adenosylmethionine (SAM) then to ACC. ${ }^{8 \sim 10)} \mathrm{SAM}$ is pivotal in the biosynthesis of both polyamines and ethylene. Thus, polyamines and ethylene have been thought to be related biosynthetically. 
Results reported in literatures cited above indicated that ethylene produced might be important in changes in the polyamine levels in plant tissues. We investigated how polyamines and ethylene biosynthetic pathways were regulated in the callus after auxin withdrawal. This paper describes the effects of inhibition of ethylene production on changes in the polyamine levels in Hiproly barley callus after cultivation in the absence of 2,4-D.

\section{MATERIALS AND METHODS}

Materials and chemicals. Hiproly barley (Hordeum disticum L. var. Hiproly) was used in the experiment. Spermidine, spermine, and methylglyoxal-bis(guanylhydrazone) (MGBG) were obtained from Aldrich Chemical Co, aminooxyacetic acid (AOA), SAM, and ACC from Sigma Chemicals, 1-aminoisobutyric acid (AIB) from Wako Pure Chemicals, and 2,4-dichlorophenoxyacetic acid (2,4-D) from the Tokyo Kasei Co. Aquazol-2 and L-[ $\left[{ }^{14} \mathrm{C}\right.$-carboxyl]-S-adenosylmethionine (59.8 $\mathrm{mCi} / \mathrm{mmol}$ ) were obtained from New England $\mathrm{Nu}$ clear, and L- $\left[3,4-{ }^{14} \mathrm{C}\right]$ methionine $(40 \sim 60 \mathrm{mCi} / \mathrm{mmol})$ from Commissariat a I'Energie Atomique. Murashige and Skoog's medium was obtained from Flow Laboratories.

Induction and proliferation of callus from Hiproly barley. Hiproly barley callus was induced and grown on White's medium as described in a previous paper. ${ }^{11)}$ The basal culture medium tested was Murashige and Skoog's medium. Calli were subcultured every 8 weeks. Calli were kept for at least two passages on White's medium containing $2 \mathrm{mg} / \mathrm{l}$ of $2,4-\mathrm{D}$, before experiments, and calli were transferred to Murashige and Shoog's basal media containing various concentrations of AOA, AIB, or MGBG. Hiproly barley calli at different times during cultivation were placed into Erlenmyer flasks containing a basal medium with $\mathrm{L}-\left[3,4-{ }^{14} \mathrm{C}\right]$ methionine $(1 \mu \mathrm{Ci})$. After incubation for $24 \mathrm{hr}$, the calli were removed, rinsed twice with distilled water, and stored at $-20^{\circ} \mathrm{C}$.

Polyamine extractions. Calli $(100 \mathrm{mg})$ were homogenized in $1 \mathrm{ml}$ of chilled $5 \%$ perchloric acid with a glass homogenizer. This homogenate was centrifuged at $20,000 \times g$ for $20 \mathrm{~min}$, and the supernatant, containing the free polyamines, was stored at $-20^{\circ} \mathrm{C}$.

Benzoylation and high performance liquid chromatographic analysis of polyamines. The polyamine concentration in the extract was measured by a method modified from that of Redmond and Tseng ${ }^{12)}$ Two $\mathrm{ml}$ of $2 \mathrm{~N}$ sodium hydroxide was added to a $1.0-\mathrm{ml}$ sample followed by $10 \mu \mathrm{l}$ of benzoyl chloride. The mixture was shaken with a Vortex mixer for $45 \mathrm{sec}$, and left for $20 \mathrm{~min}$. Two $\mathrm{ml}$ of saturated sodium chloride solution was added and the solution was extracted with $4 \mathrm{ml}$ diethyl ether. After centrifugation at $1,500 \times g$ for $15 \mathrm{~min}$, two $\mathrm{ml}$ of the upper ether phase was removed and evaporated under a stream of nitrogen. The residue was dissolved in $100 \mu \mathrm{l}$ of methanol and $10 \mu \mathrm{l}$ of the solution was used for high performance liquid chromatography (HPLC).

HPLC of benzoylpolyamines was run by a Hitachi model $655 \mathrm{~A}-11$ with an ultraviolet detector on a $8 \mathrm{NVC}_{18}$ column (radial pak, Waters Associates) at $254 \mathrm{~nm}$. A linear gradient of acetonitrile from $36.5 \%$ to $100 \%$ in $1 \%$ acetic acid over a period of $20 \mathrm{~min}$ was used as a mobile phase at a flow rate of $3 \mathrm{ml}$ per min.

Labeled polyamines were extracted by $5 \%$ perchloric acid, benzoylated by benzoyl chloride, and fractionated by HPLC as described above. One $\mathrm{ml}$ of fraction eluted from HPLC was collected in scintillation vials. Ten $\mathrm{ml}$ of Aquazol-2 was added to each vial and the radioactivity was measured by a liquid scintillation counter. Specific incorporation of ${ }^{14} \mathrm{C}$ activity into polyamines was defined as $\mathrm{dpm}$ per one $\mathrm{nmol}$ of polyamines per $24 \mathrm{hr}$.

Ethylene assay. Hiproly barley calli were placed in vials containing Murashige and Skoog's medium with or without $10 \mu \mathrm{m} 2,4-\mathrm{D}$, and vials were sealed with rubber septa. After $24 \mathrm{hr}$ in the dark, $1 \mathrm{ml}$ air samples were taken with gas-tight syringes.

Ethylene in the samples was measured by a gas chromatograph (GC) (Hitachi, model 073) with a flame ionization detector. A 2-m column containing Porapack Q of 80 to 100 mesh was used at $80^{\circ} \mathrm{C}$ with $\mathrm{N}_{2}$ gas as the carrier at a flow rate of $40 \mathrm{~cm}^{3}$ per min.

\section{Extraction and gas chromatographic analysis of ACC.} ACC was measured by GC after its conversion to ethylene by the method of Lizada and Yang. ${ }^{13)}$ Calli $(1.0 \mathrm{~g})$ were homogenized in $1 \mathrm{ml}$ of $3 \%$ sulfosalicylic acid with a glass homogenizer. The homogenate was centrifuged for $2 \mathrm{~min}$. The precipitate was extracted three times with $1 \mathrm{ml}$ of $3 \%$ sulfosalicylic acid. The supernatant was put on a column of Dowex $50 \times 8\left(\mathrm{H}^{+}\right.$form) (bed volume, $0.5 \mathrm{ml}$ ). After the column was washed with $6 \mathrm{ml}$ of water, the ACC fraction was eluted with $3 \mathrm{ml}$ of $3 \mathrm{~N} \mathrm{NH}_{4} \mathrm{OH}$. The eluate was concentrated in vacuo at $40^{\circ} \mathrm{C}$, and the residue was dissolved in $1.0 \mathrm{ml}$ of water. Seven hundred $\mu \mathrm{l}$ of the sample, $100 \mu \mathrm{l}$ of $10 \mathrm{mM} \mathrm{HgCl}_{2}$ and $800 \mu \mathrm{l}$ of distilled water were placed in glass vials. The vials were sealed with rubber septa and chilled on ice-water for $15 \mathrm{~min}$. One hundred $\mu \mathrm{l}$ of $\mathrm{NaOCl}$ reagent $(5 \% \mathrm{NaOCl}$ and saturated $\mathrm{NaOH}=2: 1, \mathrm{v} / \mathrm{v}$ ) was introduced into the reaction vials by a syringe. The vials were agitated on a Vortex mixer for $30 \mathrm{sec}$ to liberate ethylene. Liberated ethylene was measured by GC. The contents of ACC were defined as nmol of ethylene produced per gram of callus.

The radioactivity of ACC was measured by liberated ethylene. ${ }^{14)}$ Ethylene was absorbed into mercury per- 
chlorate. The absorbed radioactivity was measured by a liquid scintillation counter. Specific incorporation of ${ }^{14} \mathrm{C}$ activity into ACC was defined as dpm per nmol of ACC per $24 \mathrm{hr}$.

Preparation and assay of enzymes. For preparation of SAMDCase, a callus was homogenized in a glass homogenizer with $1 \mathrm{ml}$ of $10 \mathrm{~mm}$ sodium phosphate buffer $(\mathrm{pH} 7.5)$ containing $0.1 \mathrm{~mm}$ dithiothreitol and $1 \mathrm{~mm}$ pyridoxal-5'phosphate at $4^{\circ} \mathrm{C}$. The homogenate was centrifuged at $12,000 \times g$ for $20 \mathrm{~min}$ at $0^{\circ} \mathrm{C}$. The supernatant fraction was used for the SAMDCase assay.

The SAMDCase was measured by a method modified from that of Montague et al. ${ }^{15}$ The reaction was started by adding $100 \mu \mathrm{l}$ of crude enzyme to $10 \mu \mathrm{l}$ of $\mathrm{L}-\left[{ }^{14} \mathrm{C}\right.$ carboxyl]-S-adenosylmethionine and $10 \mu \mathrm{l}$ of $5 \mathrm{~mm}$ pyridoxal-5'-phosphate. The reaction mixture was placed in a Warburg flask. A 7-mm diameter filter paper disc (Whatman No. 1) was impregnated with $100 \mu 1$ of $2 \mathrm{~N}$ potassium hydroxide and then used to trap the ${ }^{14} \mathrm{CO}_{2}$ liberated. After incubation at $37^{\circ} \mathrm{C}$ for $60 \mathrm{~min}$, the reaction was stopped with $0.5 \mathrm{ml}$ of $1 \mathrm{~N}$ sulfuric acid, and incubated for an additional $60 \mathrm{~min}$, after which the paper discs were removed, dried, and placed in vials containing $1 \mathrm{ml}$ of distilled water and $10 \mathrm{ml}$ of Aquazol-2. ${ }^{14} \mathrm{C}$ activity was measured by a scintillation counter. The enzyme activity is expressed as ${ }^{14} \mathrm{CO}_{2}$ nmol per $\mathrm{mg}$ of protein per hours.

For the preparation of ACC synthase, a callus was homogenized in a glass homogenizer with $1 \mathrm{ml}$ of $100 \mathrm{~mm}$ HEPES buffer ( $\mathrm{pH} 8.5$ ) containing $4 \mathrm{~mm}$ dithiothreitol, $0.5 \mathrm{~mm}$ pyridoxal- $5^{\prime}$-phosphate, and $10 \mathrm{~mm}$ EDTA at $4^{\circ} \mathrm{C}$. The homogenate was centrifuged $12,000 \times g$ for $20 \mathrm{~min}$ at $0^{\circ} \mathrm{C}$. The supernatant was dialyzed with $2 \mathrm{~mm}$ HEPES buffer ( $\mathrm{pH} 8.5$ ) containing $0.5 \mathrm{~mm}$ dithiothreitol and $0.5 \mu \mathrm{M}$ pyridoxal-5'-phosphate for $12 \mathrm{hr}$ at $4^{\circ} \mathrm{C}$. The dialyzed supernatant was used for the ACC synthase assay.

The ACC synthase was measured by a method modified from that of Boller et al. ${ }^{16)}$ The reaction was started by adding $200 \mu \mathrm{l}$ of $50 \mathrm{~mm}$ HEPES buffer ( $\mathrm{pH} 8.5$ ) containing $600 \mu \mathrm{M} \mathrm{SAM}$ to $500 \mu \mathrm{l}$ of crude enzyme. After incubation at $30^{\circ} \mathrm{C}$ for $4 \mathrm{hr}$, the amounts of ACC produced were measured by the method described above.

Enzyme protein was measured by the method of Lowry et al. ${ }^{17)}$

\section{RESULTS}

Changes in the incorporation of $\mathrm{L}-\left[3,4-{ }^{14} C\right]$ methionine into polyamines and $A C C$, and the activities of SAMDCase and ACC synthase in Hiproly barley callus after auxin withdrawal

In Hiproly barley callus after auxin withdrawal, the changes in the incorporation of $\mathrm{L}^{-}$ $\left[3,4-{ }^{14} \mathrm{C}\right]$ methionine into polyamines and the

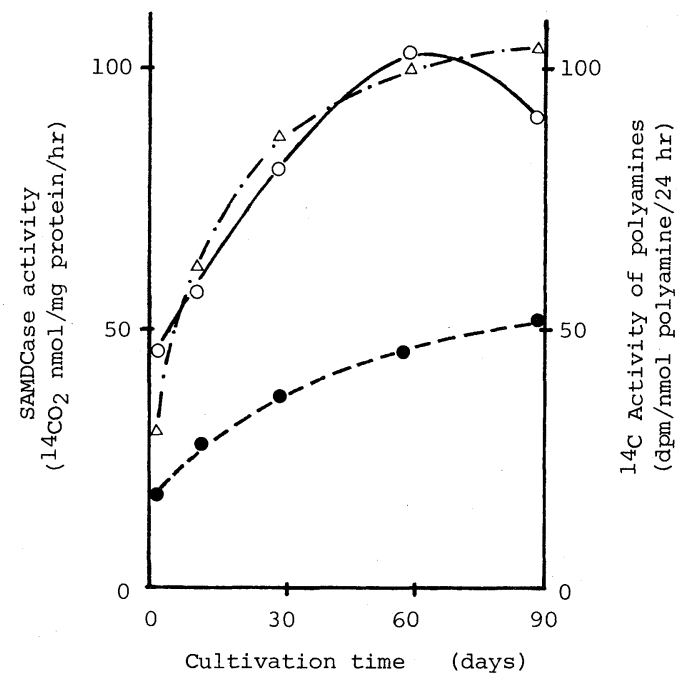

FIG. 1. Incorporation of $\mathrm{L}-\left[3,4-{ }^{14} \mathrm{C}\right]$ Methionine into Polyamines and $S$-Adenosylmethionine Decarboxylase (SAMDCase) Activity in Hiproly Barley Callus after Auxin Withdrawal.

Calli at various stages were incubated for $24 \mathrm{hr}$ in the presence of $\mathrm{L}-\left[3,4-{ }^{14} \mathrm{C}\right]$ methionine $(1 \mu \mathrm{Ci})$, and ${ }^{14} \mathrm{C}$ activities of polyamines and the activity of SAMDCase were measured.

$\bigcirc$, spermidine; $\bigcirc$, spermine; $\triangle$, SAMDCase.

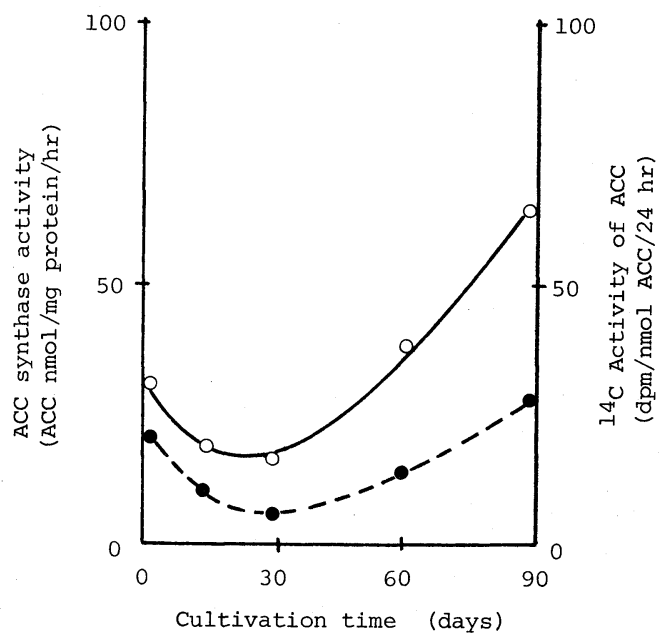

FIG. 2. Incorporation of $\mathrm{L}-\left[3,4-{ }^{14} \mathrm{C}\right]$ Methionine into 1Aminocyclopropane-1-carboxylic Acid (ACC) and ACC Synthase Activity in Hiproly Barley Callus after Auxin Withdrawal.

Calli at various stages were incubated for $24 \mathrm{hr}$ in the presence of $\mathrm{L}-\left[3,4-{ }^{14} \mathrm{C}\right]$ methionine $(1 \mu \mathrm{Ci})$, and the ${ }^{14} \mathrm{C}$ activity of $\mathrm{ACC}$ and $\mathrm{ACC}$ synthase activity were measured

O, ACC;, ACC synthase. 
Table I. Effects of 1-Aminoisobutyric Acid (AIB), Aminooxyacetic Acid (AOA), And Methylglyoxal-bis(Guanylhydrazone) (MGBG) on the Polyamine Levels of Hiproly Barley Callus

\begin{tabular}{|c|c|c|c|c|c|c|c|}
\hline \multirow{3}{*}{ Chemical } & \multirow{3}{*}{$\begin{array}{l}\text { Concentration } \\
(\mathrm{mm})\end{array}$} & \multicolumn{6}{|c|}{ Cultivation time } \\
\hline & & \multicolumn{2}{|c|}{7 th day } & \multicolumn{2}{|c|}{ 14th day } & \multicolumn{2}{|c|}{30 th day } \\
\hline & & Spd & Spm & Spd & Spm & Spd & Spm \\
\hline & & \multicolumn{6}{|c|}{$\mathrm{nmol} / \mathrm{g}$ callus } \\
\hline Control & - & 52.1 & 13.1 & 63.8 & 18.2 & 79.3 & 32.0 \\
\hline \multirow[t]{2}{*}{ AIB } & 1.0 & 66.2 & 16.7 & 69.4 & 19.5 & 100.2 & 26.5 \\
\hline & 5.0 & 67.7 & 18.9 & 71.7 & 22.5 & 100.6 & 23.4 \\
\hline \multirow[t]{2}{*}{$\mathrm{AOA}$} & 0.5 & 82.2 & 25.6 & 114.9 & 28.0 & 90.9 & 39.7 \\
\hline & 1.0 & 86.2 & 26.3 & 105.1 & 32.9 & 97.7 & 43.0 \\
\hline \multirow[t]{2}{*}{ MGBG } & 1.0 & 61.4 & 16.5 & 59.7 & 19.3 & 59.2 & 20.0 \\
\hline & 10.0 & 66.1 & 17.9 & 54.4 & 15.5 & 58.3 & 8.5 \\
\hline
\end{tabular}

Spd, spermidine; Spm, spermine.

activity of SAMDCase are shown in Fig. 1. When the callus was deprived of 2,4-D, specific incorporation of ${ }^{14} \mathrm{C}$ into polyamines and SAMDCase activity in the callus increased greatly, then remained stable. In the absence of 2,4-D, changes in the specific incorporation of ${ }^{14} \mathrm{C}$ into polyamines paralleled changes in the activity of SAMDCase.

Figure 2 shows changes in the incorporation of $\mathrm{L}-\left[3,4-{ }^{14} \mathrm{C}\right]$ methionine into $\mathrm{ACC}$ and the activity of ACC synthase in the callus after auxin withdrawal. The changes in the activity of ACC synthase paralleled the changes in the specific incorporation of ${ }^{14} \mathrm{C}$ activity into ACC. The incorporation of $\mathrm{L}-\left[3,4-{ }^{14} \mathrm{C}\right]$ methionine into ACC and ACC synthase activity first decreased, then increased.

The results of Figs. 1 and 2 demonstrated that changes in the polyamine biosynthesis are symmetrically related to changes in the ACC production. Hiproly barley callus placed on Murashige and Skoog's medium without 2,4$\mathrm{D}$ formed adventitious roots by the 30th day of cultivation. The symmetrical relationship between polyamines and ACC continued until complete adventitious roots were formed.

Effects of $A I B, A O A$, and $M G B G$ on changes in the levels of polyamines and $A C C$ in Hiproly barley callus

This experiment was designed to observe the
TABle II. EFFeCtS OF 1-AminoISObUTyric ACID (AIB), Aminooxyacetic Acid (AOA), and MethylGLYOXAL-BIS(GUANYLHYDRAZONE) (MGBG) ON THE 1-AMINOCYCLOPROPANE-1-CARBOXYLIC Acid (ACC) Production of Hiproly Barley Callus

\begin{tabular}{|c|c|c|c|c|}
\hline \multirow{2}{*}{ Chemical } & \multirow{2}{*}{$\begin{array}{l}\text { Concentration } \\
\text { (mM) }\end{array}$} & \multicolumn{3}{|c|}{ Cultivation time } \\
\hline & & 7 th day & 14 th day & 30 th day \\
\hline & & \multicolumn{3}{|c|}{ ACC $\mathrm{nmol} / \mathrm{g}$ callus } \\
\hline Control & - & 48.5 & 35.6 & 23.2 \\
\hline \multirow[t]{2}{*}{ AIB } & 1.0 & 31.5 & 32.1 & 24.7 \\
\hline & 5.0 & 47.4 & 31.7 & 27.5 \\
\hline \multirow[t]{2}{*}{ AOA } & 0.5 & 47.5 & 5.1 & 1.7 \\
\hline & 1.0 & 37.3 & 3.5 & 1.5 \\
\hline \multirow[t]{2}{*}{ MGBG } & 1.0 & 44.6 & 55.8 & 45.2 \\
\hline & 10.0 & 50.1 & 73.6 & 68.2 \\
\hline
\end{tabular}

effects of AOA, AIB, and MGBG on changes in the levels of polyamines in Hiproly barley callus that had been deprived of 2,4-D for a period of 30 days.

When MGBG was used to inhibit specific steps in the polyamine biosynthesis, spermidine and spermine synthesis were repressed. Table I indicates a strong inhibition of the biosynthesis of spermidine and spermine at a millimolar concentration of MGBG. Levels of spermidine and spermine were reduced by $10 \mathrm{~mm}$ MGBG to about $30 \%$ and $70 \%$, respectively, of the controls on the 30 th day after cultivation. 
Table III. Effects of 1-Aminoisobutyric Acid (AIB), Aminooxyacetic Acid (AOA), and Methylglyoxal-Bis(Guanylhydrazone) (MGBG) on ${ }^{14} \mathrm{C}$ Activities OF SPERMIDINE AND SPERMINE

\begin{tabular}{|c|c|c|c|c|c|c|c|}
\hline \multirow{3}{*}{ Chemical } & \multirow{3}{*}{$\begin{array}{c}\text { Concentration } \\
(\mathrm{mm})\end{array}$} & \multicolumn{6}{|c|}{${ }^{14} \mathrm{C}$ Activity } \\
\hline & & \multicolumn{3}{|c|}{ 14th day } & \multicolumn{3}{|c|}{30 th day } \\
\hline & & Spd & Spm & Total* & Spd & Spm & Total* \\
\hline & & \multicolumn{6}{|c|}{$\mathrm{dpm} / \mathrm{nmol}$ polyamine $/ 24 \mathrm{hr}$} \\
\hline Control & - & 58.7 & 30.0 & 51.5 & 79.3 & 32.1 & 72.4 \\
\hline \multirow[t]{2}{*}{ AIB } & 1.0 & 58.7 & 64.3 & 54.8 & 99.5 & 103.0 & 65.3 \\
\hline & 5.0 & 72.6 & 64.7 & 70.6 & 124.4 & 84.4 & 83.5 \\
\hline \multirow[t]{3}{*}{$\mathrm{AOA}$} & 0.5 & 98.7 & 95.5 & 98.1 & 201.8 & 167.0 & 99.7 \\
\hline & 1.0 & 191.0 & 177.5 & 188.3 & 244.4 & 219.2 & 201.6 \\
\hline & 5.0 & 153.3 & 213.2 & 165.3 & 141.2 & 256.6 & 88.4 \\
\hline \multirow[t]{2}{*}{ MGBG } & 1.0 & 79.2 & 19.3 & 69.2 & 68.9 & 21.3 & 31.1 \\
\hline & 10.0 & 25.2 & 27.6 & '25.5 & 28.4 & 1.4 & 9.0 \\
\hline
\end{tabular}

Calli were incubated for $24 \mathrm{hr}$ in the presence of the indicated concentration of AIB, AOA, or MGBG, and L-[3,4${ }^{14} \mathrm{C}$ ]methionine $(1 \mu \mathrm{Ci})$, and ${ }^{14} \mathrm{C}$ activities of spermidine $(\mathrm{Spd})$ and spermine $(\mathrm{Spm})$ were measured.

* Contents of spermidine plus spermine.

To find whether polyamine biosynthesis was stimulated by the inhibition of ethylene production, AOA and AIB were added to the culture medium. The effects of AOA and AIB on polyamine levels in the callus are shown in Table I. Compared with those of the control, the levels of spermidine and spermine in the callus rapidly increased after cultivation in the medium containing $1 \mathrm{~mm}$ or $0.5 \mathrm{~mm}$ AOA. AIB had no significant effect on changes in the levels of spermidine or spermine in the callus.

The effects of AOA, AIB, and MGBG on changes in the levels of ACC in the callus are shown in Table II. The ACC production in the callus was prevented by AOA, but not by AIB. On the other hand, ACC production was greatly enhanced by MGBG. The contents of ACC in the callus increased about 3-fold after treatment with $10 \mathrm{~mm}$ MGBG.

Effects of $A I B, A O A$, and $M G B G$ on the incorporation of $\mathrm{L}-\left[3,4-{ }^{14} \mathrm{C}\right]$ methionine into polyamines and $\mathrm{ACC}$ in Hiproly barley callus

This experiment was designed to observe the changes in the incorporation of methionine into polyamines and ACC in Hiproly barley callus.
Table IV. EFFects of 1-Aminoisobutyric AcID (AIB), Aminooxyacetic ACID (AOA), And MethylGLYOXAL-BIS(GUANYLHYDRAZONE) (MGBG) ON ${ }^{14}$ C ACTIVITY OF 1-AMINOCYCLOPROPANE1-CARBOXYLIC ACID (ACC)

\begin{tabular}{|c|c|c|c|}
\hline \multirow{2}{*}{ Chemical } & \multirow{2}{*}{$\begin{array}{l}\text { Concentration } \\
(\mathrm{mM})\end{array}$} & \multicolumn{2}{|c|}{${ }^{14} \mathrm{C}$ Activity } \\
\hline & & 14th day & 30 th day \\
\hline & & \multicolumn{2}{|c|}{$\mathrm{dpm} / \mathrm{nmol} \mathrm{ACC} / 24 \mathrm{hr}$} \\
\hline Control & - & 19.1 & 16.4 \\
\hline \multirow[t]{2}{*}{ AIB } & 1.0 & 15.6 & 10.0 \\
\hline & 5.0 & 16.7 & 9.1 \\
\hline \multirow[t]{3}{*}{$\mathrm{AOA}$} & 0.5 & 13.5 & 7.0 \\
\hline & 1.0 & 12.0 & 6.9 \\
\hline & 5.0 & 7.3 & 6.6 \\
\hline \multirow[t]{2}{*}{ MGBG } & 1.0 & 17.8 & 23.7 \\
\hline & 10.0 & 35.8 & 35.0 \\
\hline
\end{tabular}

Calli were incubated for $24 \mathrm{hr}$ in the presence of the indicated concentration of $\mathrm{AIB}, \mathrm{AOA}$, or MGBG, and L$\left[3,4-{ }^{14} \mathrm{C}\right]$ methionine $(1 \mu \mathrm{Ci})$, and then ${ }^{14} \mathrm{C}$ activity of ACC was measured.

Table III shows the effects of AIB, AOA, and MGBG on the incorporation of $\mathrm{L}-[3,4-$ ${ }^{14} \mathrm{C}$ ]methionine into polyamines in the callus. The rates of the incorporation of L-[3,4${ }^{14} \mathrm{C}$ ]methionine into polyamines increased greatly when the callus was transferred to the medium containing AOA. In the presence of 
$1 \mathrm{~mm}$ AOA, specific incorporation of ${ }^{14} \mathrm{C}$ activity into spermidine and spermine increased about 4 and 3-fold respectively, over the control. MGBG strongly inhibited the incorporation of $\mathrm{L}-\left[3,4-{ }^{14} \mathrm{C}\right]$ methionine into polyamines. On the 30 th day after cultivation, specific incorporation of ${ }^{14} \mathrm{C}$ activity into polyamines in the callus treated with $10 \mathrm{~mm}$ MGBG had decreased by about $90 \%$ of the control.

Table IV shows the effects of AOA, AIB, and $\mathrm{MGBG}$ on the incorporation of $\mathrm{L}-[3,4-$ ${ }^{14} \mathrm{C}$ ]methionine into ACC in the callus. Strong inhibition of the incorporation of $\mathrm{L}-[3,4-$ ${ }^{14} \mathrm{C}$ ]methionine into ACC was observed at millimolar levels of AOA. Specific incorporation of ${ }^{14} \mathrm{C}$ activity into $\mathrm{ACC}$ decreased by about $40 \%$ of the control. MGBG stimulated the incorporation of $\mathrm{L}-\left[3,4-{ }^{14} \mathrm{C}\right]$ methionine into ACC. On the 14th and 30th days after cultivation, specific incorporation of ${ }^{14} \mathrm{C}$ activity into ACC was increased about 2 and 3fold respectively by $10 \mathrm{~mm}$ MGBG: On the other hand, AIB had only a slight effect on the incorporation of methionine into either ACC or into polyamines (Tables III and IV).

\section{Effects of $A I B, A O A$, and $M G B G$ on the ac-} tivities of SAMDCase and ACC synthase in Hiproly barley callus

Table V shows the effects of AOA, AIB, and MGBG on the activity of SAMDCase, which is the rate-limiting enzyme in the pathway of polyamine biosynthesis. When AOA was used to inhibit the conversion of SAM to ACC, the activity of SAMDCase in the callus was greatly elevated. On the 14th and 30th days after cultivation, the activity of SAMDCase was increased about 3 and 2-fold respectively by $1 \mathrm{~mm}$ AOA, as compared with the control. AIB, which inhibited the conversion of ACC to ethylene, had no significant effect on the activity of SAMDCase. When MGBG was used to inhibit the decarboxylation of SAM, the activity of SAMDCase in the callus was inhibited about $40 \%$ by $10 \mathrm{~mm} \mathrm{MGBG}$, as compared with the control.

Table VI shows the effects of AOA, AIB,
TABle V. EfFects of 1-Aminoisobutyric Acid (AIB), Aminooxyacetic AcID (AOA), AND METHYLGLYOXAL-BIS(GUANYLHYDRAZONE) (MGBG) on THE ACTIVITY OF $S$-AdENOSYLMETHIONINE DeCARboXYlase (SAMDCase) of Hiproly Barley Callus

\begin{tabular}{|c|c|c|c|}
\hline \multirow{2}{*}{ Chemical } & \multirow{2}{*}{$\begin{array}{l}\text { Concentration } \\
(\mathrm{mm})\end{array}$} & \multicolumn{2}{|c|}{ SAMDCase activity } \\
\hline & & 14 th day & 30 th day \\
\hline \multicolumn{4}{|c|}{${ }^{14} \mathrm{CO}_{2} \mathrm{nmol} / \mathrm{mg}$ protein $/ \mathrm{hr}$} \\
\hline Control & - & 64.2 & 89.7 \\
\hline \multirow[t]{2}{*}{ AIB } & 1.0 & 73.9 & 92.2 \\
\hline & 5.0 & 67.4 & 112.9 \\
\hline \multirow[t]{2}{*}{$\mathrm{AOA}$} & 0.5 & 106.6 & 130.7 \\
\hline & 1.0 & 162.0 & 169.6 \\
\hline \multirow[t]{2}{*}{ MGBG } & 1.0 & 69.8 & 61.4 \\
\hline & 10.0 & 58.0 & 52.6 \\
\hline
\end{tabular}

Table VI. EFFects of 1-Aminoisobutyric Acid (AIB), Aminooxyacetic ACID (AOA), AND MethylGLYOXAL-BIS(GUANYLHYDRAZONE) (MGBG) ON THE ACTIVITY OF 1-AMINOCYCLOPROPANE1-CARboXYlic ACID (ACC) SYNTHASE OF Hiproly Barley Callus

\begin{tabular}{|c|c|c|c|}
\hline \multirow{2}{*}{ Chemical } & \multirow{2}{*}{$\begin{array}{l}\text { Concentration } \\
(\mathrm{mM})\end{array}$} & \multicolumn{2}{|c|}{ ACC synthase activity } \\
\hline & & 14th day & 30 th day \\
\hline & \multicolumn{3}{|c|}{$\mathrm{ACC} \mathrm{nmol} / \mathrm{mg}$ protein $/ \mathrm{hr}$} \\
\hline Control & - & 11.7 & 7.6 \\
\hline \multirow[t]{2}{*}{ AIB } & 1.0 & 14.3 & 6.7 \\
\hline & 5.0 & 13.2 & 6.7 \\
\hline \multirow[t]{2}{*}{$\mathrm{AOA}$} & 0.5 & 9.2 & 5.7 \\
\hline & 1.0 & 7.8 & 5.2 \\
\hline \multirow[t]{2}{*}{ MGBG } & 1.0 & 15.6 & 8.5 \\
\hline & 10.0 & 26.0 & 18.8 \\
\hline
\end{tabular}

and MGBG on the activity of ACC synthase, which is the rate-limiting enzyme in the pathway of ethylene production. The activity of ACC synthase was inhibited by AOA, but not by AIB. On the other hand, when the callus was transferred to the medium with MGBG, ACC synthase activity in the callus increased greatly. On the 14th and 30th days after cultivation, elevated activity of ACC synthase by $10 \mathrm{~mm}$ MGBG was about 2-fold, as compared with the control.

\section{DISCUSSION}

Giovanelli et al. ${ }^{18)}$ have reported that in 
Lemna pauciostata Hegelm, the biosynthesis of SAM is the major pathway for methionine metabolism. Adams and Yang ${ }^{8)}$ and Boller et $a l{ }^{16)}$ demonstrated that ACC was produced from SAM, and was an immediate precursor of ethylene. Moreover, SAM serves as a source of aminopropyl moieties for the biosynthesis of spermidine and spermine, as well as a substrate for the production of ACC. ${ }^{3)}$

In many plant tissues, ${ }^{8 \sim 10,16,18)}$ ethylene biosynthesis is thought to be processed by the conversion of methionine to SAM and then to ACC. Moreover, polyamine biosynthesis is processed by the decarboxylation of SAM, and incorporation of aminopropyl moieties into polyamines.

With regard to Hiproly barley callus after auxin withdrawal, our results indicated that L$\left[3,4-{ }^{14} \mathrm{C}\right]$ methionine was incorporated into both ACC and polyamines, and that the changes in the polyamine levels were symmetrically related to the changes in the contents of ACC. Furthermore, the contents of ACC decreased when the levels of polyamines in the callus increased, while elevated ACC production induced to decrease the levels of polyamines. Thus, these two compounds are produced by the conversion of methionine to SAM as in other plant tissues, and the biosynthesis of polyamines can be thought to be closely related to the regulation of ACC production.

In Hiproly barley callus, the addition of AOA induced a marked increase in the levels of spermidine and spermine. The incorporation of $\mathrm{L}-\left[3,4-{ }^{14} \mathrm{C}\right]$ methionine into polyamines increased greatly in the callus treated with AOA. Moreover, the activity of SAMDCase, deciding the fate of which SAM is committed to the polyamine pathway, was strongly stimulated in vivo by AOA. On the other hand, MGBG, which is an effective inhibitor of SAMDCase, had a significant effect on the biosynthesis of ACC. The incorporation of $\mathrm{L}-\left[3,4-{ }^{14} \mathrm{C}\right]$ methionine into ACC and the activity of ACC synthase were greatly elevated by MGBG. These results suggest that the restriction of $\mathrm{ACC}$ production is pivotal in the mechanism leading to elevated polyamine levels in the callus. This hypothesis is supported by the results whereby the addition of AIB, which inhibits ethylene evolution by blocking the conversion of ACC to ethylene, had no significant effect on the biosynthesis of polyamines and ACC. Therefore, in the case of Hiproly barley callus, the biosynthesis of polyamines is thought to be regulated by ethylene, and to inhibit ethylene formation.

\section{REFERENCES}

1) T. A. Smith, "The Biochemistry of Plants, Secondary Plant Products," Vol. 7, ed. by E. E. Conn, Academic Press, New York, 1980, pp. 249 268.

2) Y. M. Heimer, Y. Misraki and U. Bachrach, FEBS Lett., 104, 146 (1979).

3) S. S. Cohen, R. Balint and R. K. Sindhu, Plant Physiol., 68, 1150 (1981).

4) A. Apelbaum, A.-C. Burgoon, J. D. Anderson, M. Lieberman, R. Ben-Arie and A. K. Mattoo, Plant Physiol., 68, 453 (1981).

5) J. C. Suttle, Phytochemistry, 20, 1477 (1981).

6) D. R. Roberts, M. A. Walker, J. E. Thompson and E. B. Dubroff, Plant Cell Physiol., 25, 315 (1984).

7) Z. Even-Chen, A. K. Mattoo and R. Goren, Plant Physiol., 69, 385 (1982).

8) D. O. Adams and S. F. Yang, Proc. Natl. Acad. Sci. U.S.A., 76, 170 (1979).

9) L. Lürssen, K. Nauman and R. Schröden, $Z$. Pflanzenphysiol., 92, 285 (1975).

10) N. E. Hoffman and S. F. Yang, J. Am. Soc. Hortic. Sci., 105, 492 (1980).

11) Y. Katoh, T. Hasegawa, T. Suzuki and T. Fujii, Agric. Biol. Chem., 48, 1405 (1984).

12) J. W. Redmond and A. Tseng, J. Chromatogr., 170, 479 (1979).

13) C. C. Lizada and S. F. Yang, Ann. Biochem., 100, 140 (1979).

14) R. E. Young, H. K. Pratt and J. B. Biale, Anal. Chem., 24, 551 (1952).

15) M. J. Montague, J. W. Koppenbrink and E. G. Jaworski, Plant Physiol., 62, 430 (1978).

16) T. Boller, R. C. Herner and H. Kende, Planta, 145, 293 (1979).

17) O. H. Lowry, N. J. Rosebrough, A. L. Farr and R. J. Randall, J. Biol. Chem., 193, 265 (1951).

18) J. Giovanelli, S. H. Mudd and A. H. Datko, Plant Physiol., 78, 555 (1985). 